\title{
OPPORTUNITIES AND DIRECTIONS OF RURAL TOURISM DEVELOPMENT IN THE REPUBLIC OF SERBIA
}

\author{
Milan Janković1 \\ Larisa Jovanović
}

DOI: https://doi.org/10.31410/tmt.2020.375

\begin{abstract}
Rural tourism is a specific form of tourism, in which the main motive is travel to ecologically clean landscapes and the return of man to his historical roots. Rural tourism was created based on preserving the nature of rural areas and cultural and historical identity. Rural tourism is considered a new form of modern tourism together with already developed conventional forms of tourism. Rural tourism can be considered a very important form of sustainable tourism.
\end{abstract}

Modern global trends such as nature protection, health care, especially during a pandemic, staying in nature, as well as preserving and reviving local traditions, customs, cultural and historical events and manifestations have contributed to the development of rural tourism in the world. Rural tourism successfully incorporates all these elements into its offer, which is why more and more tourists travel to rural areas. Interest in rural tourism arises from the desire to escape from urban centers pressed by industrialization and man-made environmental pollution.

At present, rural tourism is one of the potentially important segments of the tourist offer on the Serbian market. Rural tourism includes a large number of activities that take place in rural areas. However, its potential is only partially valorized through rural tourism operators located in the central and northern regions of Serbia, as well as Vojvodina.

Given that financial problems are often an obstacle in the realization of most ideas, financial support is a necessary lever for the development of rural tourism and rural regions in general. EU funds can be a chance to achieve financial support for the improvement of development potentials, better promotion, networking of tour operators and the implementation of tourism projects.

Keywords: Rural tourism, Rural area, Development potential, Sustainable development, Benefit, Nature protection, Financial support, EU funds, Organic production, Cluster, Diversification, Marketing, Promotion, Serbia.

\section{INTRODUCTION}

$\mathrm{T}$ he twenty-first century has brought a significant strategic shift in the tourism sector: from mass tourism to alternative forms of ecotourism in response to growing uncertainty caused by global climate change and structural changes in consumer behavior patterns. As a result, the desire of a large number of city dwellers to travel to peaceful rural areas is growing, where they can get comfortable accommodation in country houses and walk freely in the fields and forests, breathing fresh air. Ethno food in rural households and the opportunity to participate in field work or recreate in the fresh air have a special attraction for tourists. Especially in the conditions of the COVID-19 pandemic, ecological rural tourism is considered the best suitable form

\footnotetext{
$1 \quad$ Alfa BK University, 3 Palmira Toljatija, 11070 Belgrade, Serbia

2 University Union - Nikola Tesla, FPSP, Jurija Gagarina 149a, 11070 Belgrade, Serbia
} 
of tourism for city dwellers, frightened by the possibility of getting a life-threatening illness and tired of crowds in shopping malls and queues in front of pharmacies and banks.

The concept of rural tourism is not exactly defined. Because of it, rural tourism is subject to many interpretations. There are several definitions of rural tourism. Rural tourism is defined as a form of tourism that takes place in rural areas and contains elements of an authentic rural setting on a tourist farm or in a rural hotel (OECD, 1994).

Rural tourism is considered a sustainable, multifunctional form of tourism based on local resources and traditional agricultural activities.

Rural tourism is very diverse and fragmented in terms of operational structures, activities, markets and operating environment. Rural tourism includes farm-based holidays but also adventure, hunting, educational travel, arts and heritage tourism, ethnic tourism (Roberts, Hall, 2001).

„Rural tourism is a term used when the rural environment and culture become key components of a tourism product" (UNWTO, 2004).

Any form of tourism that showcases the rural life, art, culture, and heritage at rural locations, thereby benefiting the local community economically and socially, as well as enabling interaction between the tourists and the locals for a more enriching tourism experience, can be termed as rural tourism (Irshad, 2010).

We can connect rural tourism with special forms of tourism, for example, tourism with „special interests”, such as hunting, fishing, „Scandinavian” hiking, etc. In addition, there are opportunities for active participation in certain agricultural activities and other activities related to the traditions and the way of life of the inhabitants in rural areas.

Rural tourism presupposes a temporary change of place of residence, which usually implies a stay in a space qualitatively and landscape completely different from the urban environment.

The main contribution of rural tourism is associated with the general revival and diversification of the rural economy and the creation of new products of rural tourism, generating additional income on family farms, protecting natural resources and solving the social and economic problems faced by rural residents due to the emigration of the population to other countries or moving to urban areas.

The development of rural tourism is based on small accommodation capacities, most often family facilities. The specific quality in rural tourism is based on food production, but also social contacts in an authentic environment. The growth of rural tourism depends on the willingness of local families and the local community to get involved in its development.

As presented at the Congress on Rural Tourism, annual expenditures in rural tourism amount to around $€ 12$ billion, and taking into account the added value and multiplier effects, revenues reach a figure of around $€ 26$ billion. In addition, it is estimated that rural tourism creates about 500,000 jobs. Italy, for example, records a growth of over 1 million annual arrivals on agro-tourism farms. Estimates indicate that more than 10\% of English farms are now involved 
in some area of ecotourism, while in some regions this share is growing up to $23 \%$, and about 10,000 farms offer bed and breakfast accommodation. The percentage of rural households offering some type of tourist accommodation in Austria is about $10 \%$, which is about 300,000 accommodation units. Also, $8 \%$ of farms in Germany and $4 \%$ in the Netherlands and France provide tourist services (Jerkić et al., 2019).

According to available data from 2017, the largest number of overnight stays in rural areas was registered in France, Germany, Switzerland, Great Britain and Italy. Also, the Czech Republic, Poland, Hungary, Latvia, Estonia and Lithuania record a significant number of visits to rural areas (https://ec.europa.eu/eurostat).

\section{GOAL AND SUBJECT OF THE RESEARCH}

The Republic of Serbia has exceptional geographical conditions and natural resources for the development of a sustainable form of tourism - rural tourism. This paper focuses on the study of the possibilities of rural tourism development in the Republic of Serbia.

The basic goal of the research is focused on the objective valorization of rural tourist resources of the Republic of Serbia and finding ways to develop rural tourism in the Republic of Serbia.

\section{POTENTIALS FOR THE DEVELOPMENT OF SUSTAINABLE RURAL TOURISM IN SERBIA}

The rural economy in Serbia is largely dependent on agriculture, with about $75 \%$ of the rural population engaged in agriculture for their own needs. $85 \%$ of the territory of the Republic of Serbia consists of rural areas. However, despite the richness of natural and cultural resources, rural areas continue to suffer from high unemployment rates, depopulation, low economic activity and declining natural resources.

The goals of sustainable development of rural tourism are focused on economic, environmental and institutional effects.

- The economic goals are: strengthening and diversification of the economy in rural areas, providing stable income to the rural population from local activities, elimination of the gray economy;

- Ecological goals in the field of environmental protection relate to the care for the preservation of ecosystems and natural heritage, reducing the use of non-renewable resources, increasing the efficiency of the use of natural resources, reducing the negative impact and pollution of the environment to an acceptable level;

- Institutional goals include control and management of the processes of sustainable development of rural tourism.

Serbia has great potential for the development of rural tourism, but the current level of competitiveness of Serbia in the field of rural tourism is not particularly high, despite the fact that there are already natural, cultural and social preconditions for development. The traditional approach to agriculture and the production of ethno-food are good potentials for the development of rural tourism. Serbia's natural resources are also favorable for the development of complementary activities such as hiking, recreation, hunting, fishing, horseback riding. Participation in the daily activities of the rural way of life is also an advantage of rural areas. For that reason, rural 
tourism is recognized as one of the priority Serbian tourist products and as one of the six key Vojvodina tourist products (Tourism Development Strategy, 2016).

In Vojvodina, farms are becoming an element of the tourist offer. In the Tourism Development Strategy of the Republic of Serbia for the period, 2016-2025 the farmsteads were, among other things, recognized as a key attraction for the rural areas of Vojvodina (Fruška gora, and the surroundings of Sremski Karlovci, Subotica, Palić, Potisje and Podunavlje) (Tourism Development Strategy, 2016). In addition to the idea and financial support, it is important to set a good legal basis. Namely, the legislation does not recognize farms as a special category, but equates them with standard accommodation units and prescribes equal conditions for them. By fulfilling the prescribed conditions, the farms lose their authenticity. Improvement of legislation and special categorization of farms is a precondition for the formation of the new tourist offer. At the level of local communities, it is necessary to design arrangements that will unite several different services and thus provide visitors with a complete experience within the tourist clusters.

The Republic of Serbia has significant and untapped potential for the development of rural tourism. Thus, for example, Serbia has the largest amount of available agricultural land (ha per capita) compared to other countries in Southeast Europe (Fig. 1). For the development of modern agriculture and organic food production, we should overcome many limiting factors and define a clear strategy.

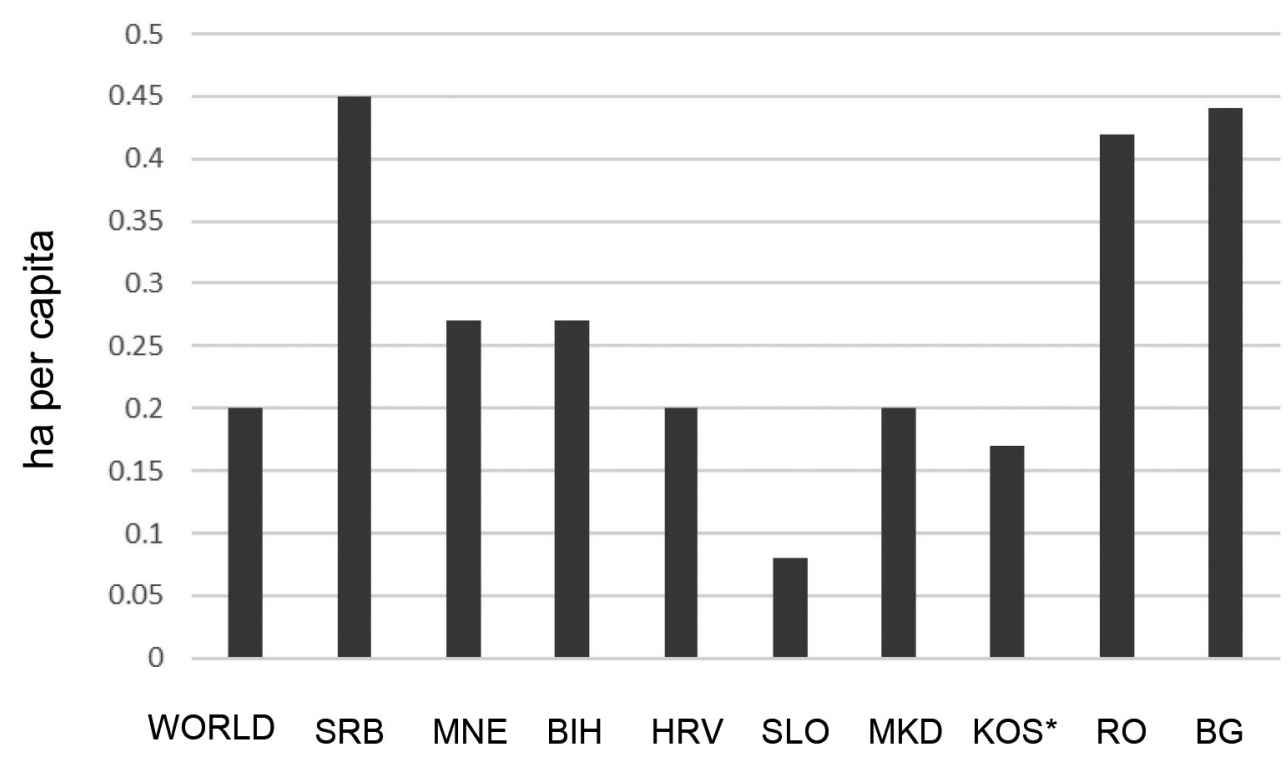

Figure 1. Available agricultural land (ha per capita) in the countries of Southeast Europe

Source: Drašković (2017)

Many rural areas are exposed to continuous processes of depopulation, economic decline and complete marginalization due to the intensive process of industrialization and urbanization. The number of inhabitants in the villages is declining, the authentic way of life and the comprehensive culture of the village are slowly disappearing due to people leaving the village, who have been the bearers and transmitters of these values for centuries. Migration from remote rural areas to urban centers that provide opportunities for better living conditions leads to the decline of rural properties and land degradation. Abandoned land is usually affected by erosion processes and other forms of degradation and pollution. Land as the main agricultural resource of Serbia should be subject to remediation (Marić et al., 2019). 
Soil degradation can be overcome by applying new agro-technical measures through remediation and reclamation. The effect of soil erosion or salinization can be reduced by applying good environmental practices (Bashkin, Galiulin, 2019). This is the case, for example, with the cultivation of land after coal exploitation, or after degradation by natural and anthropogenic factors. The area contaminated with industrial waste can also be repaired (Galiulin et al., 2020).

Land reclamation after degradation and devastation is possible in many cases. Thus, for example, ecology and environmental engineering, especially industrial ecology, have devised many usable procedures for land reclamation and bioremediation after ecological devastation and tailings pollution (Bashkin, Galiulin, 2020). Procedures of chemical-technological neutralization of acidified or saline soil are known in the world (Galiulin et al., 2020). Land remediation is achieved by phytoremediation and absorption of harmful mineral compounds (Ermakov et al., 2019).

\section{DEVELOPMENT OF ORGANIC PRODUCTION IN SERBIA}

For the development of rural tourism in Serbia, it is very important to pay attention to the production of quality healthy food. Rural tourism and organic agriculture are the main components of the green economy and green growth in agriculture (Janković et al., 2020). According to statistical data from the Ministry of Agriculture, Forestry and Water Management of the Republic of Serbia, the total area under organic production in the period 2011/2018 increased three times, while the number of producers of certified organic products, in the same reference period, doubled. Analysis of the structure of organic livestock production in the Republic of Serbia in the period 2013/2018 shows a significant increase in the number of heads of certain species, which is very important for the development of rural tourism and agro-tourism (http://www.minpolj.gov.rs/organska/).

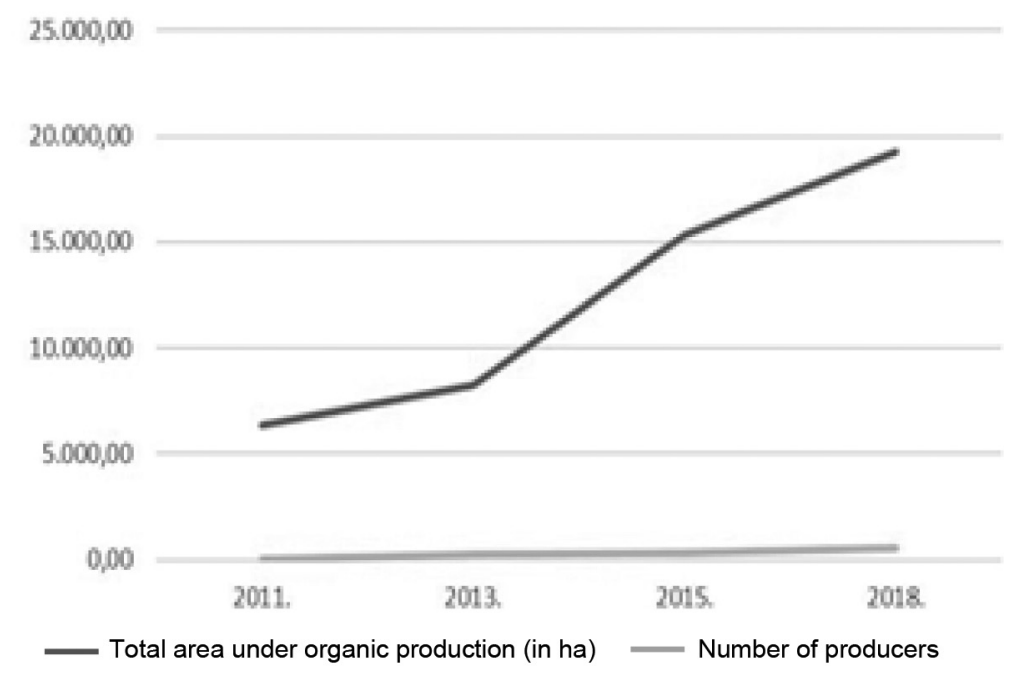

Figure 2. Total area under organic production/number of organic producers in the Republic of Serbia

Source: http://www.minpolj.gov.rs/organska/

The structure of organic livestock production is changing in the five years, so the share of poultry increased from $12 \%$ to $33 \%$, while the share of sheep increased by $10 \%$. The share of cattle decreased by $1 \%$ in the structure. In the same reference period, the number of organic cattle increased significantly, by almost $94 \%$. 
Table 1. Structure of organic livestock production in the Republic of Serbia

\begin{tabular}{|c|c|c|c|c|c|c|}
\hline \multicolumn{2}{|c|}{ Description / Year } & 2013 & 2015 & 2016 & 2017 & 2018 \\
\hline \multirow{3}{*}{ Cattle } & Organic status & 1853 & 2593 & 2560 & 3099 & 3594 \\
\hline & Conversion period & 323 & 153 & 335 & - & - \\
\hline & Total & 2176 & 2746 & 2895 & 3099 & 3594 \\
\hline \multirow{3}{*}{ Sheep } & Organic status & 2793 & 3232 & 2552 & 4665 & 5138 \\
\hline & Conversion period & 1238 & 1616 & 1826 & - & - \\
\hline & Total & 4031 & 4848 & 4378 & 4665 & 5138 \\
\hline \multirow{3}{*}{ Goats } & Organic status & 81 & 1117 & 1115 & 2048 & 1486 \\
\hline & Conversion period & 865 & 569 & 291 & - & - \\
\hline & \begin{tabular}{|l|} 
Total \\
\end{tabular} & 946 & 1686 & 1406 & 2048 & 1486 \\
\hline \multirow{3}{*}{ Pigs } & Organic status & 57 & 100 & 223 & 87 & 284 \\
\hline & Conversion period & 118 & 132 & 60 & - & - \\
\hline & Total & 175 & 232 & 283 & 87 & 284 \\
\hline \multirow{3}{*}{ Horses } & Organic status & 48 & 96 & 6 & 177 & 114 \\
\hline & Conversion period & 162 & 128 & 159 & - & - \\
\hline & Total & 210 & 218 & 165 & 177 & 114 \\
\hline \multirow{3}{*}{ Donkeys } & Organic status & 12 & 16 & 2 & 47 & 0 \\
\hline & Conversion period & 9 & 4 & 0 & - & - \\
\hline & Total & 21 & 20 & 2 & 47 & $\mathbf{0}$ \\
\hline \multirow{3}{*}{ Poultry } & Organic status & 1362 & 1079 & 3122 & 4415 & 6735 \\
\hline & Conversion period & 28 & 301 & 36 & - & - \\
\hline & Total & 1390 & 1380 & 3158 & 4415 & 6735 \\
\hline
\end{tabular}

Source: http://www.minpolj.gov.rs/organska/

In the sector of organic plant production, the growth of cereals, industrial plants and both medicinal and aromatic plants was observed (Table 2).

Table 2. Structure of organic plant production, ha (2015-2018)

\begin{tabular}{|l|l|c|c|c|c|}
\hline Description / Year & 2015 & 2016 & 2017 & 2018 \\
\hline \multirow{4}{*}{ Cereals } & Organic status & 2183 & 2192 & 2148 & 2612 \\
\cline { 2 - 6 } & Conversion period & 2069 & 2416 & 1514 & 1001 \\
\cline { 2 - 6 } & Total & $\mathbf{4 2 5 2}$ & $\mathbf{4 6 0 8}$ & $\mathbf{3 6 6 2}$ & $\mathbf{3 6 1 3}$ \\
\hline \multirow{3}{*}{ Fodder crops } & Organic status & 1043 & 806 & 999 & 905 \\
\cline { 2 - 6 } & Conversion period & 398 & 543 & 212 & 432 \\
\cline { 2 - 6 } & Total & $\mathbf{1 4 4 1}$ & $\mathbf{1 3 4 9}$ & $\mathbf{1 2 1 1}$ & $\mathbf{1 3 3 7}$ \\
\hline \multirow{3}{*}{$\begin{array}{l}\text { plands } \\
\text { plants }\end{array}$} & Organic status & 1458 & 1636 & 1444 & 1860 \\
\cline { 2 - 6 } & Conversion period & 1216 & 1281 & 847 & 102 \\
\cline { 2 - 6 } $\begin{array}{l}\text { Medicinal and } \\
\text { aromatic herbs }\end{array}$ & Total & $\mathbf{2 6 7 4}$ & $\mathbf{2 9 1 7}$ & $\mathbf{2 2 9 1}$ & $\mathbf{1 9 6 2}$ \\
\cline { 2 - 6 } & Organic status & 68 & 13 & 25 & 178 \\
\cline { 2 - 6 } & Conversion period & 3 & $\mathbf{1 1 3}$ & $\mathbf{1 1 5}$ & $\mathbf{1 9 3}$ \\
\hline
\end{tabular}

Source: http://www.minpolj.gov.rs/organska/

Table 2 shows the data on the movement of organic plant production, and the structure of plant production, for the period from 2015 to 2018. Products obtained from organic plant production were used in organic livestock production (Pešić, 2020).

Demanding trends for organic agricultural products and organic food dominate the EU markets and other developed markets (Živanović et al., 2019a). Nowadays, organic agriculture and animal husbandry are increasingly in the focus of business banking in the context of commercial lending to agriculture (Živanović et al., 2019b). 


\section{RURAL TOURISM IN SERBIA}

In the second decade of the 20th century, Serbia as a tourist destination experienced a rapid increase in the number of tourist arrivals and overnight stays. In large tourist centers every year (except for the decrease in 2020 due to the Covid-19 pandemic), about $97 \%$ of hotel capacity is recorded. The rest of Serbia, the rural hinterland, generates only 3\% of overnight stays, which can be considered problematic in terms of sustainable and balanced regional development (Statistical office of Republic of Serbia, 2019).

This type of tourism can provide additional income to residents of rural areas. The development of rural tourism benefits not only service providers but also the local economy, which receives an inflow of funds with the arrival of tourists. Also, rural tourism can contribute to the revival of forgotten folk arts and crafts. However, despite all the advantages of rural tourism, Serbia is not using its potential to its full extent. Foreigners who travel to Serbia like to see much more than rafts and festivals, because of which Belgrade, Novi Sad and Nis are known to foreign tourists. Unfortunately, information on rural tourism in Serbia is insufficient and difficult to access for foreign tourists, although many of them could be interested.

That very few foreigners go to the countryside to enjoy the natural beauties of Serbia is confirmed by a statistical review. According to the data of the Republic Bureau of Statistics, in 2016, 2.75 million tourists were registered in Serbia, who realized 7.53 million overnight stays. Out of that, 4.79 million overnight stays were realized by domestic tourists and 2.73 million overnight stays - by foreign tourists. Only 4,094 domestic tourists and 237 foreign tourists spent time in 174 rural tourist households in 18 municipalities. The municipality of Gornji Milanovac has the largest number of registered rural tourist households, a total of 47. Every year, rural tourism becomes an increasingly massive form of ecotourism and rural tourism.

There are no official data on the number of registered households engaged in rural tourism, but according to local tourism organizations, rural tourism is supported by more than 32,000 both registered and unregistered beds in rural areas, 10,000 of which are exclusively in rural areas. Also, it is estimated that this total number of beds annually brings about 10 billion dinars of income from rural tourism.

Rural environments in Serbia are rich in significant natural and cultural development resources, but despite that, villages lag far behind in development concerning urban areas. There are also village-city migrations, which are usually one-way. Representatives of different age groups of the population are moving out, especially young people, who do not see their perspective in the countryside. This is understandable because domestic agriculture is poorly competitive and inefficient, and the state helps only large exporters with its measures, while ordinary small households hardly remain ,at zero" after years of hard work.

However, rural tourism can really change the socio-economic picture of a rural area, and the positive effects are multiple: the development of rural tourism encourages the development of agriculture, as the primary activity in the countryside:

- rural tourism creates destinations, but also new jobs and preserves existing ones (in agriculture and crafts),

- the development of tourism and the arrival of tourists helps in the placement of homemade products and other forms of crafts, 
- the development of rural tourism creates new business opportunities and represents a new opportunity for young people, which would reduce the negative trend of emigration to the city and abroad,

- development of rural tourism encourages the preservation of the natural environment, local culture, traditions and customs,

- development of tourism in villages will bring greater chances for building better roads and improving infrastructure (Plojović et al., 2017).

The growth of rural tourism is quite difficult to quantify, because statistics vary between countries and many of them do not separate rural tourism from other forms. Nevertheless, most national tourist associations confirm the growth. Although some call this only a modern trend, rural and agro-tourism cannot be considered a random and short-term phenomenon, and it is believed that their growth in Europe and in the world is conditioned by the following factors (Jerkić et al., 2019):

- growing interest in cultural and natural heritage,

- increasing leisure time and disposable income of the population in cities,

- faster transport and better communication with rural areas,

- growth of environmental and health awareness,

- interest in gastronomic specialties and ethno food,

- growing interest in organic products.

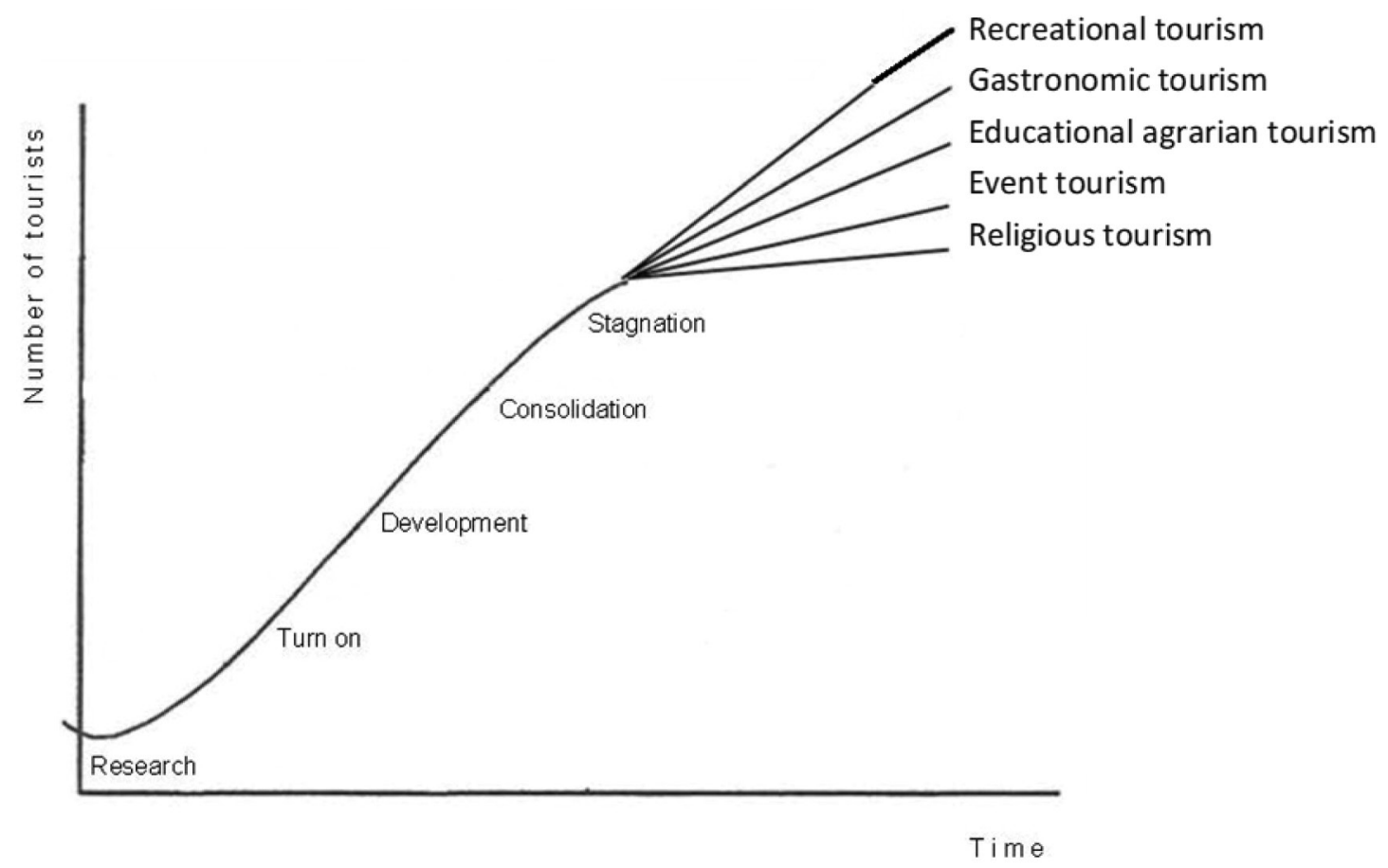

Figure 3. Life cycle diversification

Source: Modified figure from the work of Jovanović et al. (2019)

In many cases, rural tourism is an additional, multifunctional activity, which complements traditional agriculture and significantly contributes to the diversification of the traditional rural economy, improves the socio-cultural environment and provides protection of natural resources in rural areas. According to the Tourism Development Strategy of the Republic of Serbia for the period from 2016 to 2025, rural tourism includes various forms of tourism activities such as (Tourism Development Strategy, 2016): 
- agrotourism, accommodation of tourists in rural houses, on farms - participation of tourists in traditional agricultural works,

- outdoor activities - recreation and leisure (hunting, fishing, horseback riding, cycling, hiking),

- eco-tourism - tourism that supports the protection of natural resources,

- rural experience (rural tourism) - tourists immerse themselves in everyday rural life,

- cultural tourism - visit of tourists to cultural and historical monuments, archaeological excavations in rural areas,

- event tourism - song festivals, production and sale of local souvenirs and agricultural products, etc.

In addition to the primary tourism form, later in the diversification of the portfolio, it is necessary to include other forms of rural-tourism that will innovate tourism eco-destinations and thus increase the number of target groups of tourists, and improve the profitability of tourism company (Fig. 3). Rural areas can also serve to open up new eco-destinations or to diversify portfolios and clusters with other forms of ecotourism (Mitrovic et al., 2019).

\section{LIMITING FACTORS OF INTENSIVE DEVELOPMENT OF RURAL TOURISM IN THE REPUBLIC OF SERBIA}

The existence of natural resources in rural areas of the Republic of Serbia is not a sufficient condition for the development of rural tourism. They constitute a comparative advantage but what essentially makes the tourism market competitive is the ability of property owners, local municipalities, and other stakeholders to organize long-term resource use and sustainable destination development efficiently and effectively to develop rural tourism and rural prosperity.

Previous efforts in the field of rural tourism development in the Republic of Serbia have not been at a satisfactory level. First of all, the lack of cooperation between government bodies (state, municipalities, local communities) should be pointed out. In addition, many factors have consistently slowed the growth of rural tourism. Some of the most important are:

- lack of adequate tourist infrastructure and superstructure,

- poor communal and traffic infrastructure,

- lack of equipped accommodation capacities,

- insufficient care for the preservation of the environment and natural resources,

- lack of adequate staff for marketing and tourism development,

- insufficient application of modern information and communication technologies,

- inadequate distribution of financial resources for the development of rural tourism,

- demographic trends and the aging process of the rural population,

- insufficient education of interested rural households on how to receive and animate tourists (Janković et al., 2020).

There are other risk factors that can affect the development of rural tourism, such as:

- lack of quality of services provided,

- lack of qualified staff and finances, which directs them to join forces for more efficient implementation of destination and market management programs,

- lack of understanding and/or misunderstanding of the concept of rural tourism, together with incorrect initial assumptions about a simple and easy product market, income and employment, 
- non-compliance with development goals of local authorities and development agencies, as a result of inadequate communication, mistrust and lack of a common vision of development,

- lack of planning for further development and limited use of the marketing concept as a business philosophy that leads to a lack of information about the needs and desires of tourists,

- lack of funds to start and/or continue operations as a result of insufficient understanding and support from the state, banks and other financial institutions, especially in countries in transition,

- lack of information on opportunities for further development of tourism,

- lack of support from local, regional and governmental entities (Njegovan, 2016).

Limiting factors for the development of rural tourism are manifested in the lack of accommodation capacity, quality services, infrastructure, financial resources and control over the use of resources.

\section{DIGITALIZATION AND DEVELOPMENT OF MARKETING IN RURAL TOURISM}

The basic characteristics of supply and demand in rural tourism, as well as the importance of the natural and cultural environment for the development of this type of tourism, or tourism market segment, indicate the importance of marketing in order to create a basis for the rational market business. On the other hand, the fact is that special attention is paid to the development of rural tourism due to its potential contribution to social and economic renewal of rural areas (importance of tourism as a factor in providing additional income and employment, as well as repopulation and removal of social isolation of rural areas). In this sense, we can view tourism as a way to solve or overcome a number of problems in the development of rural areas around the world. Having in mind the stated relationship between the development of rural areas and the development of tourism, we can state that the market approach to relations in rural tourism must be based on respect for the social benefits arising from that relationship.

Rural tourism in Serbia is not adequately structured and organized, and the main limiting factors are primarily insufficiently trained staff in the field of rural tourism and marketing, as well as the lack of a strategy for the promotion of tourist content. The promotion strategy should determine the target group of tourists to whom the marketing messages will be directed, while on the supply side special attention should be paid to meeting specific tourist requirements. Also, in the determination of the strategy, the directions of development and contours of the tourist offer are defined in order to create the tourist identity of the destination (Janković et al., 2010).

As an example, we can mention the website www.selo.rs, which managed to collect data for about 576 agricultural farms engaged in rural tourism in addition to traditional agricultural activities. The idea is to make a serious offer, with true data provided by those agencies that are interested in convincing potential tourists of a quality offer of rural tourism.

The application of marketing in tourism is constantly being adjusted to turbulent changes in the economy and society. Along with the changes in the directions of tourism development, which are constant and strong, the very bases for the application of marketing are also changing. Current world tendencies in the application of marketing, especially in tourism, indicate its significant adjustment to social goals. Therefore, the basics for the application of marketing 
are being expanded and the goals of the entire marketing system in society are being partially revised. Thus, for example, the branding of high quality food products, as well as products with a geographical origin (primarily wine and brandy) is becoming the main trend in the marketing attractiveness of rural areas. A brand is a way in which consumers can distinguish a destination. To be effective, a brand should unify all of rural benefits (culture events, gastronomic manifestation, recreation) in the mind of the consumer (Čajka, Jovanović, 2014).

The wide social significance of the development of rural tourism points to the importance of the application of marketing by state and social institutions, organizations and associations at the local, regional and national level. It is especially important to emphasize the role and importance of national tourism organizations (NTOs), as well as appropriate organizations at the local level (tourism organizations of municipalities and cities) in order to design, present, promote and educate related to rural tourism.

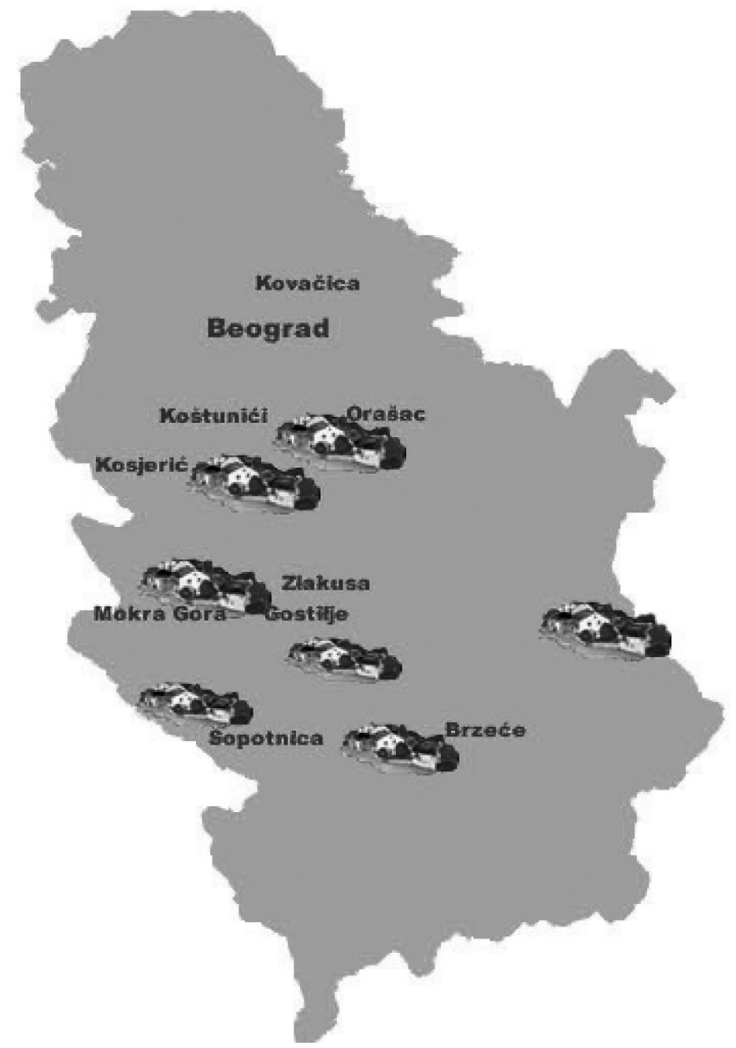

Figure 4. The most famous places for the development of rural tourism in Serbia

Source: http://www.discoverserbia.org/en/seoski-turizam

National, regional and local tourism organizations should especially support the market presence, i.e. the formation, sale and presentation of rural tourism products through market research, image creation, product development support, as well as through staff training, consulting and advisory activities to improve marketing efforts of organizations which deal with the marketing of rural tourism at the micro level (Plojović et al., 2017).

The overall process of marketing rural tourism in Serbia also faces a number of problems that may affect the market positioning of rural tourism products. The underlying problem could be defined as the existence of a mismatch between the expected benefits, by tourists, and the overall tourism product, which contains many undefined elements. 
The rural tourism venture in Serbia is mainly owned by one family and is based on limited funds for further development. These farms usually remain small and rely heavily on family members, especially women. The typical rural lifestyle is considered to be the main attraction, and therefore the protection of this intangible element of rural cultural heritage is highly recommended. In any case, a previously maintained rural area with authentic rural life is a basic source for rural tourism.

The tourist offer of rural areas in Serbia is extremely fragmented and represents a large number of micro and small regionally dispersed providers. The best picture of how developed rural tourism in Serbia is can be seen from a very small number of locations on the map of Serbia (Fig. 4). In solving these problems, the relationship between the public sector, tourism companies, regardless of the form of ownership, and organizations and individuals who are directly involved in the provision of services in rural tourism is crucial. The answer should be found in the process of appropriate planning and management of rural tourism development, especially through financing instruments.

\section{SOURCES OF FINANCING RURAL TOURISM IN SERBIA FROM EU FUNDS}

The importance of investing in rural tourism is confirmed by examples of good practice from many countries around the world. For example, the US government has implemented several regional and state development projects aimed at increasing the efficiency of rural tourism and farm activities. The governments of Australia and the United Kingdom have also offered a wide range of products and services to promote tourism in rural areas. In Europe, the tourist rural brands of France (Gites de France), Austria (Urlaub am Bauernhof) and Italy (Agroturismo) are well known.

The development of rural tourism with special emphasis on agro-farm tourism is the subject of policy of many European countries whose goal is to encourage the global social and economic development of rural areas that mainly suffer from negative trends of deagrarization and depopulation. Some of the measures taken at the local and national level are shown in Table 3.

Table 3. Incentives for the development of rural tourism in European countries

\begin{tabular}{|l|l|}
\hline State & Type of incentives and sources for the development of rural tourism \\
\hline Belgium & $\begin{array}{l}\text { The regional government subsidizes accommodation units up to 30\% of the total project } \\
\text { costs. }\end{array}$ \\
\hline Denmark & $\begin{array}{l}\text { The government subsidizes agro-tourism associations with fixed amounts of money on an } \\
\text { annual basis. }\end{array}$ \\
\hline France & $\begin{array}{l}\text { The government provides incentives to new businesses in rural areas, assists with marketing } \\
\text { activities, and conducts a feasibility study. }\end{array}$ \\
\hline Greece & $\begin{array}{l}\text { Tourism projects in the rural area of Petra Kesvos are subsidized by the government, local } \\
\text { government and the EU. }\end{array}$ \\
\hline Ireland & $\begin{array}{l}\text { The Rural Tourism Development Agency "Ballyhoura Failte Society" is funded by the } \\
\text { government, local government and the EU. }\end{array}$ \\
\hline Italy & Agro-tourist boards are funded by the government on an annual basis. \\
\hline Netherlands & $\begin{array}{l}\text { Communities, such as the "Varninging Recreatie by de Boer", are funded by the regional } \\
\text { government. }\end{array}$ \\
\hline Germany & $\begin{array}{l}\text { Incentives for the development of rural tourism are distributed at different levels: Bayern, } \\
\text { Niedersachsen, Hessen, Baden-Württemberg are financed by the regional government, and } \\
\text { Rheinland Pfalz and Schlesvig-Holstein by the regional government and other sources. }\end{array}$ \\
\hline
\end{tabular}

Source: Petric (2003) 
The IPARD program is an EU financial instrument to support rural development and agriculture. By acquiring the status of a candidate for EU membership, the Republic of Serbia has exercised the right to use European Union funds from the IPARD pre-accession component. The essence of IPARD (Instrument for Pre-Accession Assistance for Rural Development) is to provide financial support to future members of the European Union in order to successfully implement the measures of the Common Agricultural Policy EU in accordance with the principles of sustainable development of agriculture and rural development.

To finance projects, part of the funds is provided from the IPARD Fund on the principle of co-financing, and part must be financed from domestic funds, where the participation of the public sector can be a maximum of $50 \%$, while the rest must be provided from the private sector (Puškarić et al., 2015).

The assistance is intended directly for users, i.e. agricultural producers - legal entities and individuals, and the responsibility for managing this program and its implementation in Serbia lies with the Ministry of Agriculture and the Directorate for Agrarian Payments. In 2020, a new Measure 7 was introduced: diversification of agricultural holdings and business development, which refers to rural tourism. Currently, rural tourism in Serbia is financed through the IPARD fund (http://www.minpolj.gov.rs/ipard-program-2014-2020).

IPARD EU Rural Areas includes:

- investments in physical assets and costs of construction of accommodation and catering facilities,

- purchase of machinery and equipment,

- landscaping,

- construction of a local road network,

- development of tourist recreational activities,

- procurement of equipment for the use of renewable energy sources.

A serious amount of money was allocated from the EU budget, and partly from the national treasury for the construction and reconstruction of facilities for accommodation and catering or their equipment - 2.3 billion dinars. The competition is open for three months. The largest amount of IPARD support per user is 300,000 euros, and the return that can be obtained for the investment is up to 65 percent.

The minimum refund is $€ 5,000$ and the maximum is $€ 300,000$. There is a great interest in rural areas in consulting agencies that help farmers, entrepreneurs and businessmen to prepare IPARD projects.

In IPARD projects related to rural tourism, there are a number of novelties in relation to projects and public calls that farmers have had so far, and these are calls for co-financing investments in machinery and mechanization, construction and equipping of farms and warehouses, as well as orchards and greenhouses, facilities for processing fruits, vegetables, meat, milk and eggs and grapes. The procedure is not simple, especially when it comes to the construction and adaptation of the facility, and such investments are mostly within this new measure. The first condition for participation in this public invitation is that every farmer (natural person, entrepreneur, micro or small enterprise) has a farm registered in the register of agricultural farms, in active 
status. When the investment is completed, the condition related to the categorization of the rural household or the facility for accommodating guests must be met.

Therefore, the first step in dealing with rural tourism is the establishment of an agricultural farm within which the rural tourism service will take place. The facilities in which catering services will be provided (from farms to boarding houses) in a rural tourist household must be categorized and meet the minimum technical and sanitary-hygienic conditions in accordance with Measure 7 for diversification of agricultural farms and business development.

Administrative formalities significantly slow down the process of preparing applications for grants, co-financing and other forms of support from the state and European Union funds. It is necessary to prepare business plans and collect bids from construction contractors and equipment suppliers. It is also necessary to obtain permits for the reconstruction of accommodation facilities and a decision for construction works.

At the end of 2020, the Directorate for Agrarian Payments held a three-day training for the use of software for processing documentation submitted to the public calls in the field of rural development. The transition from manual to electronic processing will greatly reduce the possibility of human error, speed up the selection of candidates for admission and harmonize the process of processing cases with the practice in EU countries. Rural tourism in Serbia has development potential, especially in the situation of the Covid-19 pandemic when the population is increasingly turning to domestic tourism. The popularity of rural tourism is growing all over the world. More and more people decide to spend their holidays in nature in the countryside (www.selo.rs).

\section{RECOMMENDATIONS FOR FURTHER DEVELOPMENT OF RURAL TOURISM IN SERBIA}

The high priority given to tourism (and agriculture) as economic activities of strategic importance in several national development strategies and policies in Serbia, generates rapid growth of tourist arrivals, reaching the number of arrivals since the late , $80 \mathrm{~s}$, but still highly concentrated in destinations with large tourist centers. In the last decade, Serbia as a tourist destination has experienced a rapid increase in the number of tourist arrivals and overnight stays. Rural areas have not benefited much from tourism, except for destinations close to major tourist centers (along with Zlatibor, Vrnjacka Banja and Kopaonik) and areas and villages near Belgrade.

The rural tourism sector in Serbia represents a large number of small enterprises, mostly family-owned and developed with almost no or very little institutional support. However, the activities of domestic and foreign development agencies must be mentioned (USAID PRO program, etc.).

Future guidelines for the development of rural tourism in Serbia must be focused on (Bećirović et al, 2017):

- sustainable resource management,

- knowledge transfer and technical-technological development,

- growth of competitiveness,

- food chain and logistical support to the agricultural sector,

- development of rural areas and strengthening of social structure. 
Special attention should be paid to the association and joint appearance of tourist organizations on both the domestic and foreign markets. As important factors in the development of rural areas in Serbia, clusters and cooperatives stand out in order to achieve the development of rural tourism in various diversified fields (Mitrović et al., 2019).

The site www.selo.rs best shows how far we have come with the association in the rural tourism sector. The basic idea of the site is to gather all service providers in the field of rural tourism in one place and to enable them a joint presentation in one place. The site is both informative and sales. Through the site, the tourist can be informed about the total offer, then, after choosing a rural household that interests him, he can open its subpage and be convinced of the offer of that rural household, to look at the ratings of those who previously used the services of that household, available calendar whether and when there is a reservation, and if he finds a free term he can make a reservation directly on the site.

The disadvantage of such a presentation is that it is not possible to search farms according to certain criteria, because that would make it easier to find an ideal tourist destination for a potential guest. In any case, the effort made by the organizers of the site selo.rs is to be commended and it can be said that it is one of the better ways of joint action of the main participants in the promotion of the tourist offer of Serbia in the field of rural tourism.

\section{CONCLUSION}

Geographical diversity (lowlands, hilly areas, rivers and lakes) and the richness of natural and cultural-historical resources indicate that rural areas and more intensive development of rural tourism could play a key role in the future economic development of the Republic of Serbia. Nevertheless, the tourism of the Republic of Serbia is in the initial phase of development. Fragmented and dispersed rural holdings, the turn of tourists to other forms of tourism and insufficiently developed awareness of the value of holidays in ecologically clean rural areas are just some of the factors that have influenced the poor development of rural tourism. Insufficient financial investments in the expansion of accommodation capacities and infrastructure of rural areas has negatively affected the development of rural tourism in Serbia.

Lack of financial resources, reduced volume of tourist traffic, inadequate infrastructure, inefficient marketing and inadequate staff are important influencing factors that are responsible for the current situation of rural tourism in the Republic of Serbia.

Rural areas have the opportunity to offer different types of agricultural products in Serbia. However, the lack of branded products and products with a geographical origin does not provide rural tourism destinations with the marketing power to attract tourists.

In order to achieve the expected effects from rural tourism, it is necessary to plan and stimulate organizational action in building the tourist offer of the village. In addition, the rural tourism product needs to be locally controlled, based on authenticity and promotion that highlights realistic expectations of product use. All this would lead to faster development of rural tourism in our country, which is currently below the real possibilities. In the last decade, Serbia as a tourist destination has experienced a rapid increase in the number of tourist arrivals and overnight stays. Rural tourism is emerging as a potential driver of sustainable rural development. Rural tourism can be promoted as a means of combating the social and economic challenges facing 
rural areas in Serbia, primarily those associated with the decline of traditional sectors of the agricultural industry.

Tourism in many cases is an additional activity that provides significant support to the traditional rural economy, which primarily consists of agriculture, forestry, crafts, souvenir making and other activities. The offer of rural tourism is very rich and very dedicated to the characteristics of the area in which the tourist activity takes place. Due to this fact, it is necessary to insist on the complex promotion of rural tourism and the development of marketing activity.

Marketing should be understood, especially in relation to the development of rural tourism, as a bridge between organizations dealing with communication between local tourism companies, tourist destinations and society. Focusing the rural tourism on human needs, as well as the natural and cultural environment is the core of the concept of sustainable tourism development; it requires that the main goal of marketing in tourism is to improve the quality of life of all participants in the process.

By concerted action to increase the quality of accommodation, food and all services provided to tourists, as well as the natural and socio-cultural environment, goals can be achieved that will make rural tourism an attractive and useful activity for all participants. An insufficient number of participants in the rural tourism destinations in Serbia also indicates the shortcomings of marketing activities.

Positive experiences of European countries with developed rural tourism (Austria, Switzerland, France, Germany, Italy, Slovenia) indicate the possibility of using rural tourism as a complementary factor of economic development in rural areas of Serbia.

\section{REFERENCES}

Bashkin, V. \& Galiulin, R. (2019). Reclamation of soils of the island Bely (Russia). Ecologica, 26(95), 388-392.

Bashkin, V. \& Galiulin, R. (2020). Enzyme activity analysis at recultivation of disturbed soils in the Taz peninsula (Russia). Ecologica, 27 (97), 101-105.

Bećirović S., Plojović, Š., Ujkanović, E. \& Plojović, S. (2017). Challenges at starting an agribusiness in the hilly-mountainous regions of southwest Serbia. Ekonomika poljoprivrede, 64(4), 1669-1686.

Čajka, Z. \& Jovanović, L. (2014). Održivi marketing menadžment. Beograd: Ecologica.

Drašković, B. (Red.). (2017). Ekonomske, socijalne i razvojne posledice prodaje poljoprivrednog zemljišta u Srbiji, Beograd: Institut ekonomskih nauka.

Ermakov, V., Jovanović, L., Tyutikov, S., Safonov, V. \& Golubev, F. (2019). Accumulation of trace elements by plants of some areas of central Russia. Ecologica, 26(93), 5-9.

Galiulin, R., Galiulina, R. \& Bashkin, V. (2020). Remediation of mechanically disturbed soils in the Taz peninsula (Russia). Ecologica, 27(98), 163-168.

Irshad, H. (2010). Rural Tourism - An Overview. Government of Alberta, Agriculture and Rural Development, Canada.

Janković, D., Petrović. Ž. \& Čikić, J. (2010). Karakteristike savetodavnog procesa u radu sa odabranim gazdinstvima u Vojvodini. Ekonomika poljoprivrede, 57(2), 257-274.

Janković, M., Ivannikov, N., Jovanović L. \& Gajdobranska A. (2020). Doprinos zelene ekonomije razvoju ekoturizma i organskoj proizvodnji. Ecologica, 27(98), 217-223. 
Jerkić T., Okanović, A. \& Vukadinović, S. (2019). Značaj ruralnog turizma za privlačenje kineskih turista u Srbiju. Ecologica, 26(96), 469-474.

Jovanović, L., Živković, D., Janković, M., Šiljak V. \& Toskić D. (2019). Significance of sustainable eco-tourism for Serbia's economic development. Collection of Papers - Faculty of Geography at the University of Belgrade, 67(2), 53-67.

Marić, M., Cvetković, A. \& Žikić, S. (2019). Održivo upravljanje životnom sredinom korišćenjem tehnika fitoremedijacije zemljišta. Ecologica, 26(95), 376-382.

Mitrović, L., Mitrović, A. \& Mitrović, S. (2019). Zadruge u funkciji održivog razvoja Srbije, Ecologica, 26(93), 49-54

Njegovan, Z. (2016). Ekonomika turizma i seoskog turizma, Novi Sad: Poljoprivredni fakultet.

Pešić, B. (2020). Analiza organske stočarske i biljne proizvodnje u Srbiji. Ecologica, 27(98), 195-202.

Petric, L. (2003). Constraints and Possibilities of the Rural Tourism Development with

the Special Stress on the Case of Croatia, 43rd Congress of the European Regional Science Association, University of Jyväskylä, Jyväskylä, pp. 27

Plojović, S., Bećirović, S., Plojović, Š. \& Ujkanović, E. (2017). Models of linking recreational tourism and agribusiness through use of ICT, International Conference on Economic and Social Studies (ICESoS), Held at Sarajevo, May 2017, Volume: 1.

Puškarić, A., Mirović, V., Đokić, N., Pavlović, N. \& Medić, S. (2015). Priručnik za ruralni turizam. Novi Sad: Turistička organizacija Vojvodine.

Roberts, L. \& Hall, D. (Eds). (2001). Rural Tourism and Recreation: Principles to Practice. Oxon and New York: CABI Publishing.

Statistical office of Republic of Serbia (2019).

Tourism Development Strategy (2016) / Strategija razvoja turizma Republike Srbije za period 2016-2025. godine, Ministarstvo trgovine, turizma i telekomunikacija, Beograd, 2016.

Živanović, B. Cvejić, A. \& Aćimović, Ž. (2019a). Rizici finansiranja konvencionalnog modela proizvodnje maline u poslovnom bankarstvu Republike Srbije. Ecologica, 26(96), 535544.

Živanović, B., Cvejić, A. \& Sikimić, U. (2019b). Perspektive finansiranja organskog stočarstva modelom bankarskog kredita u Republici Srbiji. Ecologica, 26(96), 525-534.

https://ec.europa.eu/eurostat

https://www.celotajs.lv/cont/prof/assoc/definition_de.html?0\&lang=de

http://www.minpolj.gov.rs/organska/

http://www.minpolj.gov.rs/ipard-program-2014-2020/

https://www.selo.rs 
